\title{
Mastodynia: is imaging necessary in young patients?
}

\author{
Engin Ölçücüoğlu' ${ }^{1}$ Güliz Yılmaz²
}

ABSTRACT

'Clinic of General Surgery, lğdır State Hospital, Iğdır, Turkey

${ }^{2}$ Clinic of Radiology, lğdır State Hospital, lğdır, Turkey

This study was presented at the $18^{\text {th }}$ National Surgical Congress as an e-poster, 23-27 May 2012, İzmir, Turkey

\section{Address for Correspondence Dr. Engin ölçücïoğlu Clinic of General Surgery, Iğdır State Hospital, lğdır, Turkey Phone.: +90 4762260305 e-mail:drengin@gmail.com}

Received: 03.06.2012

Accepted: 09.01.2013

@Copyright 2013 by Turkish Surgical Association

Available online at www.ulusalcerrahidergisi.org
Objective: Mastalgia is the most frequent symptom seen in patients who undergo breast imaging. There are various medical treatment methods in the literature. However, malignancy should be excluded before starting treatment. This is a prospective study, evaluating the necessity of imaging in patients who have applied for cyclic or non-cyclic breast pain, with normal physical examination, and without a family history.

Material and Methods: Two hundred women, younger than 30 years of age, who applied to Iğdır State Hospital general surgery department with complaint of cyclic or non-cyclic breast pain, were prospectively studied. Patients with nipple discharge, complaint of lump in their breast, who were pregnant or lactating, who had breast cancer history in their family and those who were found to have lumps on examination were excluded from the study. All patients underwent ultrasound imaging and the same radiologist evaluated them.

Results: The breast examination was normal in all patients. Ultrasound imaging results were completely normal in 98 (48\%) patients. 47 (23.5\%) patients were found to have fibroadenoma, with a mean diameter of $9.6 \mathrm{~mm}(5 \mathrm{~mm}-14 \mathrm{~mm})$. $45(22.5 \%)$ patients had simple cysts with a mean diameter of $7.8 \mathrm{~mm}(3 \mathrm{~mm}-11 \mathrm{~mm}) .6(3 \%)$ patients were found to have intraductal papillomas and 4 (2\%) to have lipomas. All patients were classified as either BI-RADS 1 or BI-RADS 2.

Conclusion: It is recommended that malignancy should be eliminated before starting treatment in patients with breast pain. In this study, the necessity of imaging in patients younger than 30 years and who applied to the general surgery department for only breast pain, was investigated. None of the patients with a normal breast examination were found to have any lesions considered suspicious for malignancy. We believe that if breast examination is normal, the patient is equal to or younger than 30 years of age and there is no family history, imaging is not necessary and that medical therapy can be started directly after the patient is informed.

Key Words: Mastalgia, breast neoplasms, breast ultrasonography

\section{INTRODUCTION}

Mastalgia is the most common symptom in patients undergoing breast imaging (1). It affects approximately $70 \%$ of women (2). It is examined in two categories; cyclic (the level of pain can vary according to menstrual cycle phases) and non- cyclic (is not associated with the menstrual cycle), and in two-thirds of patients breast pain is cyclic (3). Cyclic breast pain is the most common type, and is more common in premenopausal women in the 30s. It is usually bilateral, and is more often felt in the upper outer quadrant. Its intensity increases just before menstruation, and decreases after menstruation. Non- cyclic pain is felt as pain related to the chest wall rather than the breast itself. It is not associated with the menstrual cycle. It may be felt either continuously or intermittently. It is rare as compared to the cyclic type and is found in women who are in their 40s. It is usually localized to one side and felt at a single area.

Pathophysiology of breast pain is not fully elucidated. High levels of serum fatty acid levels, increase in basal prolactin levels and excessive fatty diet are considered as etiologic factors (4). Psychological factors are also shown to play a role in the etiology in some studies (5).

There are various medical treatments in the literature but it is recommended that malignancy should be excluded prior to treatment. That is why majority of physicians ask for additional imaging studies even when the physical examination is normal in patients with complaints of breast pain.

In this study, the necessity of imaging in patients who have applied for cyclic or non-cyclic breast pain, with normal physical examination, and without a family history, is prospectively evaluated.

\section{MATERIAL AND METHODS}

Two hundred women, younger than 30 years of age, who applied to Iğdır State Hospital general surgery department with complaint of cyclic or non-cyclic breast pain, were prospectively studied. Pain 
scale was not used. Patients with nipple discharge, presence of a lump in their breast, who were pregnant or lactating, who had breast cancer history in their family and those who were found to have lumps on examination were excluded from the study. Imaging was performed by the same radiologist for all patients, using 10-MHz linear probe SSA-240 U.S. device (Toshiba, Osaka, Japan) for ultrasonography. None of the patients underwent any further investigation.

\section{RESULTS}

Breast examination was normal in all patients. 76 patients (38\%) had cyclic breast pain, whereas 124 patients (62\%) complained of non-cyclic breast pain. Breast pain was unilateral in 58 patients (29\%), while in 142 patients $(71 \%)$ it was bilateral. The mean age of patients was 24.6 (18-30) years, with a median age of 24. Ultrasonographic imaging findings was completely normal in 98 patients (49\%). In 47 patients (23.5\%) a fibroadenoma was detected. The mean diameter of fibroadenomas was $9.6 \mathrm{~mm}$ ( $5 \mathrm{~mm}-14 \mathrm{~mm})$. In 45 patients (22.5\%) a simple cyst was shown. The mean diameter of simple cysts was $7.8 \mathrm{~mm}$ ( $3 \mathrm{~mm}-11 \mathrm{~mm}$ ). Intraductal papillomas were detected in 6 patients (3\%), and in 4 patients (2\%) lipomas were shown (Table 1). All patients were classified as either BI-RADS 1 or BI-RADS 2.

\section{DISCUSSION}

Breast pain is a very common symptom in women that affects quality of life. Currently, with the widespread use of media and the internet, this symptom is perceived to be associated with cancer by the society. However, the probability of malignancy in patients with complaints of breast pain only is very low (6).

Although mastalgia is usually seen in the young, it can be felt in almost any age. It is recommended by many sources that malignancy should be excluded in breast pain, but there is not any consensus that specifies the age limit. In Western countries, the incidence of breast cancer under the age of 40 is around $4 \%$ per year and the vast majority of these patients are between the ages of 35-39. In a study investigating the association between mastalgia and breast cancer, 5463 patients were retrospectively evaluated and no correlation was found (4). In the literature, there is a retrospective study showing that cyclic breast pain may be related to cancer, but the mean age of patients in this study is 40 with most cases of cancer over the age of 35 (7).

There are publications showing that breast pain is more related to psychological factors (5). Psychotherapy without medical treatment has been successful in many patients. The study by Aksu et al. (8) on patients with breast pain who did not have any organic etiology, suggests the presence of psychopathol-

Table 1. Ultrasonography findings

\begin{tabular}{|lc|}
\hline Normal breast tissue & $98(49 \%)$ \\
\hline Fibroadenomatosis & $47(23.5 \%)$ \\
\hline Simple cyst & $45(22.5 \%)$ \\
\hline Intraductal papilloma & $6(3 \%)$ \\
\hline Lipoma & $4(2 \%)$ \\
\hline
\end{tabular}

ogy in patients and that these patients need psychiatric assessment. In another study by Çakır et al. (9), the severity of mastalgia showed a positive and significant correlation with depression and anxiety levels and it was observed that telkin was effective in reducing the severity of pain.

In a retrospective study by Yüksekkaya et al. (10), ultrasound findings and BI-RADS categories were similar between patients with breast pain under the age of 40 and the control group, and cancer was not detected in any patients.

In this study, the necessity of imaging in patients younger than 30 years and who presented to the general surgery clinics with only a complaint of breast was evaluated. All breast examinations were normal and no lesions suspicious for malignancy were determined. Based on these findings, we think that if the breast examination is normal, the patient is equal to or younger than 30 years of age and there is no family history, imaging is not necessary and that medical therapy can be started directly after the patient is informed.

\section{CONCLUSION}

An additional imaging study is not required to exclude malignancy in patients with complaints of breast pain, who are younger than 30 years of age, with normal breast examination and no family history.

Peer-review: Externally peer-reviewed.

Author Contributions: Study concept and design - E.Ö., G.Y.; Acquisition of data - E.Ö., G.Y.; Analysis and interpretation of data - E.Ö., G.Y.; Preparation of the manuscript - E.Ö.; Statistical analysis - E.Ö.

Conflict of Interest: No conflict of interest was declared by the authors.

Financial Disclosure: The authors declared that this study has received no financial support.

\section{REFERENCES}

1. Mansel RE. Clinical Assessment of mastalgia. Br J Clin Pract Suppl 1989; 43: 17-9.

2. Gateley CA, Holland PA. Drug therapy of mastalgia. What are the options? Drugs 1994; 48: 709-16. [CrossRef]

3. Watt-Boolsen S, Eskildsen PC, Blaehr H. Release of prolactin, thyrotropin and growth hormone in women with cyclical mastalgia and fibrocystic disease of the breast. Cancer 1985; 56: 500-2. [CrossRef]

4. Seema A. Khan, A. Vania Apkarian. Mastalgia and breast cancer: a protective association? Cancer Detection and Prevention 2002; 26: 192-6. [CrossRef]

5. Fox H, Walker LG, Heys SD, Ah-See AK, Eremin O. Are patients with mastalgia anxious, and does relaxation therapy help? The Breast 1997; 6: 138-42. [CrossRef]

6. Preece PE, Baum M, Mansel RE, Webster DJ, Fortt RW, Gravelle IH, et al. Importance of mastalgia in operable breast cancer. $\mathrm{Br}$ Med J (Clin Res Ed) 1982; 284: 1299-300. [CrossRef]

7. Plu-Bureau G, Thalabard JC, Sitruk-Ware R, Asselain B, Mauvais-Jarvis $P$. Cyclical mastalgia as a marker of breast cancer susceptibility: results of a case-control study among French women. $\mathrm{Br} J$ Cancer 1992; 65: 945-9. [CrossRef]

8. Aksu G, Hocaoğlu Ç. Evaluation of Anxiety, Alexytimia and Depression levels in patients undergoing Radiologic Evaluation for Mastalgia. Klinik Psikiyatri 2004; 7: 95-102 
9. Çakır T, Cingi A, Nurhan F, Bez Y, Topçuoğlu V, Güllüoğlu BM. The importance of assurance in patients with mastalgia unrelated to organic causes. Meme Sağlığı Dergisi 2006; 2: 96-9.
10. Yüksekkaya R, Çelikyay F, Voyvoda N, Gökdemir Ö. Breast ultrasonography findings in patients with complaint of mastalgia and younger than 40 years. Meme Sağlığı Dergisi 2012; 8: 19-22. 